\title{
ALK NM_004304.4:C.3522C>A
}

National Cancer Institute

\section{Source}

National Cancer Institute. ALK NM 004304.4:C.3522C C A. NCI Thesaurus. Code C146865.

A nucleotide substitution at position 3522 of the coding sequence of the ALK gene where cytosine has been mutated to adenine. 